\title{
Probiotic supplemented diets improved the performance of broiler chickens during
} wet season

${ }^{1}$ Buba, W., ${ }^{2}$ Ugboga, J. O., ${ }^{1}$ Yunusa, A. and ${ }^{1}$ Shehu, B. M.

${ }^{1}$ National Agricultural Extension and Research Liaison Services, Ahmadu Bello University, Zaria

${ }^{2}$ Animal Science Department, Ahmadu Bello University, Zaria, Kaduna State

Department of Pharmacology and Toxicology, Faculty of Veterinary Medicine, Ahmadu Bello University, Zaria

Corresponding author: bubawahe@gmail.com; +2348065399885

\section{Abstract}

Probiotics, a live microbial feed supplement affects the host animal by improving its intestinal microbial balance. Thus, this study was conducted to determine the effect of probiotic (Saccharomyces cerevisiae) supplemented diets on the performance of broilers chickens during the wet season. Two hundred and fifty five broilers chickens were randomly allotted to five treatments in a complete randomize design (CRD) with three replicate per treatment, each replicate having 17 birds. Saccharomyces cerevisiae was included at 0\%, $0.25 \%, 0.5 \%, 0.75 \%$ and $1 \%$ respectively. Feed intake was measured weekly and the birds were weighed once weekly to determine the weight improvement. Data obtained from the study were subjected to analysis of variance. All parameters (final body weight, body weight gain, average daily gain, total feed intake, average feed intake and feed conversion ratio) measured showed significance $(P<0.05)$ difference when compared with the birds on control diets. In conclusion, inclusion of baker's yeast in broiler diet improved growth performance of the chickens.

Keywords: Probiotics, performance and broiler chickens

\section{Introduction}

Probiotics is defined as "a live microbial feed supplement which beneficially affects the host animal by improving its intestinal microbial balance" (Fuller 1989). Over the last several years considerable attention has been given to the use of probiotics and other natural feed additives in poultry feed. Much of this interest has been generated because of increased public awareness and objection to the use of antibiotic as a growth promoter (Al-Homidan and Fahmy, 2007). Intestinal function is affected by diets fed to the animal and also the season of production, many kinds of natural substances such as prebiotics and probiotics have been supplemented to broilers to increase production by activating intestinal function, but there is limited information about the effect of different seasons on the performance of broilers supplemented with Saccharomyces cerevisiae as a probiotic in the tropics. The basis of this study was to investigate the effect of baker's yeast (saccharomyces cerevisiae) suplementation as probiotic in broiler chickens diet during the rainy season.

\section{Materials and methods Experimental site}

The study was conducted at the Skills Acquisition and Development Centre of National Agricultural Extension and Research Liaison Services, Ahmadu Bello University, Zaria. The institute is located within the Northern Guinea Savannah Zone of Nigeria at latitude $11^{\circ} 09^{\prime} 06^{\prime \prime} \mathrm{N}$ and longitude $7^{0} 38^{\prime} 55^{\prime \prime} \mathrm{E}$, at an altitude of $706 \mathrm{~m}$ above sea level (GPS, 2014). The area has 
an average annual rainfall of $1100 \mathrm{~mm}$, which starts from late April or early May to mid-October. The mean maximum temperature varies from $26^{\circ} \mathrm{C}$ to $35^{\circ} \mathrm{C}$ depending on the season, while the mean relative humidity during rainy season is 72\% (Akpaetal., 2002).
Experimental diets

Five experimental diets were formulated to meet the nutrient requirement of broilers. Diet 1 served as the control while diets 2, 3, 4 , and 5 contain $0.25,0.50,0.75$ and $1.00 \%$ Saccharomyces cerevisiae, respectively. The composition of the diets for starter phase is shown in Table 1 while that of finisher phase is shown in Table 2.

Table 1: Composition of broiler starter diets containing varying levels of Saccharomyces cerevisiae (1-4weeks)

\begin{tabular}{|c|c|c|c|c|c|}
\hline \multirow[b]{2}{*}{ Ingredients } & \multicolumn{3}{|c|}{ Probiotic inclusion (\%) } & \multirow[b]{2}{*}{$\begin{array}{l}4 \\
\mathrm{SC} 0.75\end{array}$} & \multirow[b]{2}{*}{$\begin{array}{l}5 \\
\text { SC } 1.00\end{array}$} \\
\hline & $\begin{array}{l}1 \\
\text { SC } 0.0\end{array}$ & $\begin{array}{l}2 \\
\text { SC } 0.25\end{array}$ & $\begin{array}{l}3 \\
\text { SC } 0.50\end{array}$ & & \\
\hline Maize & 50.66 & 50.63 & 50.60 & 50.55 & 50.52 \\
\hline Groundnut cake & 25.31 & 24.81 & 24.31 & 23.82 & 23.32 \\
\hline Soya cake & 12.59 & 12.59 & 12.59 & 12.59 & 12.59 \\
\hline Palm oil & 3.69 & 3.72 & 3.75 & 3.79 & 3.82 \\
\hline Limestone & 0.90 & 0.90 & 0.90 & 0.90 & 0.90 \\
\hline Bone meal & 2.75 & 2.75 & 2.75 & 2.75 & 2.75 \\
\hline Common Salt & 0.30 & 0.30 & 0.30 & 0.30 & 0.30 \\
\hline Premix $* *$ & 0.30 & 0.30 & 0.30 & 0.30 & 0.30 \\
\hline Lysine & 0.30 & 0.30 & 0.30 & 0.30 & 0.30 \\
\hline Methionine & 0.20 & 0.20 & 0.20 & 0.20 & 0.25 \\
\hline Total & 100.00 & 100.00 & 100.00 & 100.00 & 100.00 \\
\hline
\end{tabular}

SC: Saccharomyces cerevisiae

Table 2: Composition of broiler finisher diets containing varying levels of Saccharomyces cerevisiae (5-8 weeks)

\begin{tabular}{|c|c|c|c|c|c|}
\hline \multirow{3}{*}{ Ingredients } & \multicolumn{3}{|c|}{ Probiotic inclusion (\%) } & \multirow[b]{2}{*}{4} & \multirow[b]{2}{*}{5} \\
\hline & 1 & 2 & 3 & & \\
\hline & SC 0.0 & SC 0.25 & SC 0.50 & SC 0.75 & SC 1.00 \\
\hline Maize & 57.52 & 57.52 & 57.52 & 57.52 & 57.52 \\
\hline Groundnut cake & 11.67 & 11.17 & 10.67 & 10.17 & 9.67 \\
\hline Soya cake & 20.00 & 20.00 & 20.00 & 20.00 & 20.00 \\
\hline Palm oil & 2.81 & 2.81 & 2.81 & 2.81 & 2.81 \\
\hline Limestone & 1.10 & 1.10 & 1.10 & 1.10 & 1.10 \\
\hline Bone meal & 2.80 & 2.80 & 2.80 & 2.80 & 2.80 \\
\hline Common Salt & 0.30 & 0.30 & 0.30 & 0.30 & 0.30 \\
\hline Premix $* *$ & 0.30 & 0.30 & 0.30 & 0.30 & 0.30 \\
\hline Lysine & 0.30 & 0.30 & 0.30 & 0.30 & 0.30 \\
\hline Methionine & 0.20 & 0.20 & 0.20 & 0.20 & 0.20 \\
\hline Total & 100.00 & 100.00 & 100.00 & 100.00 & 100.00 \\
\hline
\end{tabular}

SC: Saccharomyces cerevisiae

\section{Experimental design}

Two hundred and fifty-five, 1-day-old broiler chicks of Ross white strain were used for this study. The design of the experiment was a completely randomize design. The average weight of the birds was recorded and then the birds were randomly divided into five treatments of 45 chicks 


\section{Buba, Ugboga, Jyunusa and Shehu}

each. Each group was subdivided into three replicate pens of 15 chicks each. The birds were reared in deep litter system under strict managerial and hygienic conditions. Feed and water were provided ad libitum during the experimental period. The first treatment (T1) was used as the control and fed the starter and finisher basal diet while the second (T2), third (T3) fourth (T4) and fifth (T5) treatments were fed the basal diet supplemented with $0.5,1.0,1.5$ and $2.0 \%$ commercial dry yeast (Saccharomyces cerevisiae), respectively. All diets were formulated to meet the nutrient requirements of the chicks. Vaccines against Newcastle and Gomboro diseases were given following the vaccination schedule of the study area. Anti-stress was given to the birds after each vaccination.

\section{Measurement of growth performance}

Feed consumption and body weight of the birds were recorded weekly. Body weight gain was calculated as the difference between the final weight and the initial weight. Feed conversion was calculated as the ratio between feed intake and weight gain.

\section{Statistical analysis}

Data obtained from all the experiments were subjected to the analysis of variance (ANOVA) using the General Linear Model procedure of (SAS, 2001). Significant differences among treatment means were separated using the Duncan's Multiple Range Test in the SAS, version 9.0 package.

\section{Result and discussion Effect of inclusion of SC:Saccharomyces cerevisiae $(S C)$ in the diet of broilers on growth Performance}

Table 3 shows the effect of inclusion of saccharomyces cerevisiea in the diet of broilers on growth performance during the starter phase. Significant $(\mathrm{P}<0.05)$ differences were observed for all the measured parameters (final body weight, body weight gain, daily gain, total feed intake, average feed intake and feed conversion ratio) measured. $\mathrm{T}_{4}$ had the best final body weight although not statistically different from $T_{5}$. T5 recorded the best (2.05) feed conversion ratio among the dietary treatments.

Table 4 shows the effect of inclusion of Saccharomyces cerevisiea in the diet of broilers on growth performance at finisher phase. The result revealed significant $(\mathrm{P}<0.05)$ differences for all the measured parameters. $T_{5}$ had the best performance in terms of final body weight and feed conversion ratio. Birds fed the control diet consumed more feed (2675.5g) compared to other treatment groups.

The result of this study is also in line with the report by kabir et al. (2004) who reported high weight gain in bird fed with probiotic supplemented diet. This could be as a result of the microbes present in probiotic which would secrete some enzymes (amylase, protease and lipase) which would enhance the catalytic activities of the endogenous enzymes and then help to improve the growth performance of the birds.Also the best weight observed in $T_{5}$ could be due to digestive tract activity whereby Saccharomyces cerevisiae in the gut inhibit the growth of pathogenic microbes by increasing acidity of the intestinal contents thereby providing a pathogenic free intestinal medium for proper functioning of endogenous enzymes to breakdown the energy nutrients of the experimental rations thus in turn improve body weight gain and feed conversion ratio (Altaf-Ur-Rahman, 2007). 
Probiotic supplemented diets improved the performance of broiler chickens during wet season

Table 3: Effect of inclusion of Saccharomyces cerevisiae in the diet of broilers on growth performance (0-4wks)

\begin{tabular}{lcccccc}
\hline \multirow{2}{*}{ Parameters } & \multicolumn{5}{c}{ Dietary Treatments } & \multirow{2}{*}{ SEM } \\
\cline { 2 - 5 } & $\mathbf{T}_{\mathbf{1}}$ & $\mathbf{T}_{\mathbf{2}}$ & $\mathbf{T}_{\mathbf{3}}$ & $\mathbf{T}_{\mathbf{4}}$ & $\mathbf{T}_{\mathbf{5}}$ & \\
\hline Initial body weight (g) & 41.18 & 41.18 & 41.18 & 41.18 & 41.18 & \\
Final body weight (g) & $524.51^{\mathrm{b}}$ & $526.47^{\mathrm{b}}$ & $565.68^{\mathrm{a}}$ & $579.41^{\mathrm{a}}$ & $578.43^{\mathrm{a}}$ & 17.85 \\
Body weight gain (g) & $483.33^{\mathrm{b}}$ & $485.29^{\mathrm{b}}$ & $524.50^{\mathrm{a}}$ & $538.23^{\mathrm{a}}$ & $537.25^{\mathrm{a}}$ & 17.85 \\
Av daily gain (g) & $28.43^{\mathrm{b}}$ & $28.55^{\mathrm{b}}$ & $30.85^{\mathrm{a}}$ & $31.94^{\mathrm{a}}$ & $31.60^{\mathrm{a}}$ & 1.03 \\
Total Feed Intake(g) & $1133.74^{\mathrm{b}}$ & $1121.35^{\mathrm{b}}$ & $1094.68^{\mathrm{b}}$ & $1375.29^{\mathrm{a}}$ & $1092.14^{\mathrm{b}}$ & 43.18 \\
Average Feed Intake(g/d) & $66.69^{\mathrm{b}}$ & $65.96^{\mathrm{b}}$ & $64.39^{\mathrm{b}}$ & $80.90^{\mathrm{a}}$ & $64.24^{\mathrm{b}}$ & 2.54 \\
F C R & $2.35^{\mathrm{a}}$ & $2.31^{\mathrm{ab}}$ & $2.10^{\mathrm{b}}$ & $2.58^{\mathrm{a}}$ & $2.05^{\mathrm{b}}$ & 0.12 \\
\hline
\end{tabular}

abc. Means with different superscripts along same rows show significant differences $(\mathrm{P}<0.05)$

SEM: Standard Error of Means

Table 4: Effect of inclusion of Saccharomyces cerevisiae in the diet of broilers on growth performance (5-8wks)

\begin{tabular}{lcccccc}
\hline \multirow{2}{*}{ Parameters } & \multicolumn{5}{c}{ Dietary Treatments } & \multirow{2}{*}{ SEM } \\
\cline { 2 - 5 } & $\mathbf{T}_{\mathbf{1}}$ & $\mathbf{T}_{\mathbf{2}}$ & $\mathbf{T}_{\mathbf{3}}$ & $\mathbf{T}_{\mathbf{4}}$ & $\mathbf{T}_{\mathbf{5}}$ & \\
\hline Initial body weight (g) & 579.41 & 579.41 & 579.41 & 579.41 & 579.41 & \\
Final body weight $(\mathrm{g})$ & $1545.10^{\mathrm{c}}$ & $1701.96^{\mathrm{bc}}$ & $1662.74^{\mathrm{bc}}$ & $1721.57^{\mathrm{b}}$ & $1788.24^{\mathrm{a}}$ & 30.66 \\
Body weight gain $(\mathrm{g})$ & $995.09^{\mathrm{c}}$ & $1151.96^{\mathrm{b}}$ & $1112.73^{\mathrm{b}}$ & $1171.57^{\mathrm{b}}$ & $1238.23^{\mathrm{a}}$ & 30.66 \\
Av daily gain (g) & $58.54^{\mathrm{c}}$ & $67.76^{\mathrm{b}}$ & $65.46^{\mathrm{b}}$ & $68.92^{\mathrm{b}}$ & $72.84^{\mathrm{a}}$ & 1.80 \\
Total Feed Intake(g) & $2675.5^{\mathrm{a}}$ & $2423.5^{\mathrm{ab}}$ & $2425.5^{\mathrm{ab}}$ & $2240.2^{\mathrm{b}}$ & $2133.3^{\mathrm{b}}$ & 132.17 \\
Average Feed Intake(g/d) & $157.38^{\mathrm{a}}$ & $142.56^{\mathrm{ab}}$ & $142.68^{\mathrm{ab}}$ & $131.78^{\mathrm{b}}$ & $125.49^{\mathrm{b}}$ & 7.78 \\
F C R & $2.68^{\mathrm{a}}$ & $2.10^{\mathrm{bc}}$ & $2.19^{\mathrm{b}}$ & $1.91^{\mathrm{c}}$ & $1.72^{\mathrm{c}}$ & 0.11 \\
\hline
\end{tabular}

abc: Means with different superscripts along same rows show significant differences $(P<0.05)$

SEM: Standard Error of Means

\section{Conclusion}

It is concluded from the study that poultry farmers should include $1.0 \%$ Saccharomyces cerevisiae in broilers diet for enhanced growth performance.

\section{References}

Akpa, G. N., Ifut, O. J. and Mohammed, F. 2002. Indigenous management of Dystocia in ruminant livestock of northern guinea savannah of Nigeria.Nigeria Journal Animal Production 29(2):264-70

Al-Homidan, A. and Fahmy, M. O. 2007. The effect of dried yeast (Saccharomyces Cerevisiae) supplementation on growth performance, carcass chemical analysis, immunity, ileum villi heights and bacterial count of broiler chickens.Egypt Poultry
Science, 27(111):613-623.

Altaf-Ur-Rahman, M., Sultan, S. and Ahmad, N. 2007. Effect of dietary probiotic supplementation on performance of broilers.Sarhad Journal of Agriculture, 23(2):482484.

Fuller, R. 1989. Probiotics in man and animals.Journal of Applied Bacteriology, 66:365-378.

GPS (Global Positioning System), 2014

Kabir, S. M. L., Rahman, M. M., Rahman, M. B. and Ahmed, S. U. 2004. The dynamics of probiotics on growth performance and immune response in broilers. International Journal of Poultry Science, 3:361-364.

SAS, 2001. SAS User's Guide. Version 6.11. SAS Institute, Inc. Cary, NC.

Received: 3rd September, 2017 Accepted: 30th November, 2017 